
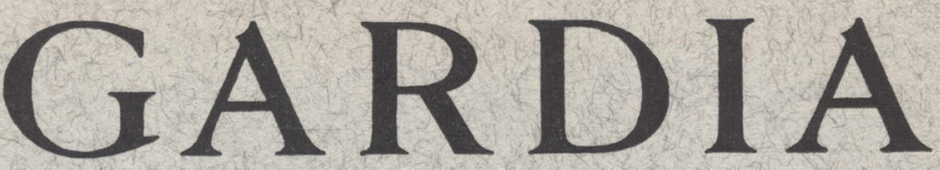

A Journal of Agricultural Science Published by the California Agricultzoral Experiment Station

\title{
A STUDY OF THE EFFECT \\ OF IRRIGATION WATER COMPOSITION ON SOIL PROPERTIES
}

K. L. BABCOCK, R. M. CARLSON, R. K. SCHULZ, and R. OVERSTREET

UNIVERSITY OF CALIFORNIA - BERKELEY, CALIFORINIA 
Lysimeter experiments designed to study the quality of irrigation waters were initiated in 1953 . The principal objective was to observe the effects of $\mathrm{Na}^{+}$and $\mathrm{HCO}_{3}^{-}$in the water on the chemical properties of the soil. After being cropped to alfalfa for four years, the soil was found to have significant salt gradients with depth. In many cases, there was an appreciable formation of exchangeable $\mathrm{Na}^{+}$, and "excess cation saturation" had been induced. Extensive chemical analyses are reported. 


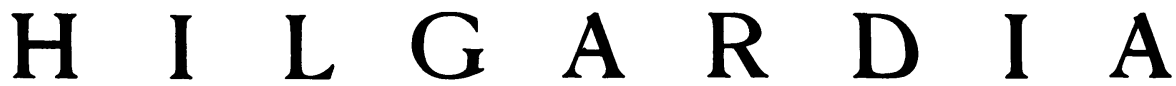

A Journal of Agricultural Science Published by

the California Agricultural Experiment Station

VoL. 29

OCTOBER, 1959

No. 3

\section{A STUDY OF THE EFFECT OF IRRIGATION WATER COMPOSITION ON SOIL PROPERTIES}

\author{
K. L. BABCOCK, ${ }^{2}$ R. M. CARLSON, ${ }^{3}$ R. K. SCHULZ, ${ }^{4}$ and R. OVERSTREET ${ }^{5}$
}

\section{INTRODUCTION}

All waters used to irrigate plants contain dissolved salts. Thus, if irrigation water is repeatedly evaporated and transpired by plants in a given mass of soil, the salt content of the soil will increase until it eventually becomes injurious to plants. Extensive research has been done on the amount of leaching necessary to prevent such salt accumulation, and on related problems.

When the cation content of irrigation water is characterized by a high proportion of $\mathrm{Na}^{+}$, the use of such water may increase the exchangeable $\mathrm{Na}^{+}$ content of the soil, resulting in injury to plants and possibly a poor soil condition. Eaton $(1950)^{6}$ suggested that such effects may be aggravated if the irrigation water contains $\mathrm{HCO}_{3}{ }^{-}$ions. As water containing $\mathrm{Ca}^{++}$and $\mathrm{HCO}_{3}{ }^{-}$ evaporates, $\mathrm{CO}_{2}$ is lost from the system, and $\mathrm{CaCO}_{3}$ precipitates according to the reaction:

$$
\mathrm{Ca}^{++}+2 \mathrm{HCO}_{3}^{-} \rightleftharpoons \mathrm{CaCO}_{3(\mathrm{~s})}+\mathrm{H}_{2} \mathrm{O}+\mathrm{CO}_{2}
$$

Thus, as a soil containing soluble $\mathrm{Ca}^{++}$and $\mathrm{HCO}_{3}{ }^{-}$dries out, $\mathrm{CaCO}_{3}$ is precipitated, and the ratio of $\mathrm{Na}^{+}$to $\mathrm{Ca}^{++}$ions in the soil solution increases. This in turn results in an increase in the exchangeable $\mathrm{Na}^{+}$content. Effects of this kind have been clearly demonstrated (Richards, 1954). Eaton (1950) has therefore suggested that irrigation waters be evaluated on the basis of the "possible" sodium percentage of the water. That is, where the $\left(\mathrm{HCO}_{3}{ }^{-}+\mathrm{CO}_{3}{ }^{3}\right)$ does not exceed $\left(\mathrm{Ca}^{++}+\mathrm{Mg}^{++}\right)$, "possible" $\mathrm{Na}^{+}$percentage $=$

$$
\frac{\mathrm{Na}^{+}}{\left(\mathrm{Ca}^{++}+\mathrm{Mg}^{++}+\mathrm{Na}^{+}\right)-\left(\mathrm{HCO}_{3}^{-}+\mathrm{CO}_{3}^{--}\right)} \times 100 .
$$

\footnotetext{
${ }^{1}$ Received for publication February 5, 1959.

${ }^{2}$ Assistant Professor of Soil Chemistry and Assistant Soil Chemist in the Experiment Station, Berkeley.

${ }^{3}$ Senior Laboratory Technician in the Experiment Station, Berkeley.

${ }^{4}$ Assistant Specialist in Soils and Plant Nutrition in the Experiment Station, Berkeley.

${ }^{5}$ Professor of Soil Chemistry and Soil Chemist in the Experiment Station, Berkeley.

"See "Literature Cited" for citations referred to in the text by author and date.
} 
This represents the Na percentage which results when part of the $\mathrm{Ca}^{++}$and $\mathrm{Mg}^{++}$is precipitated as carbonates. When the $\left(\mathrm{HCO}_{3}{ }^{-}+\mathrm{CO}_{3}{ }^{\circ}\right)$ exceeds the $\left(\mathrm{Ca}^{++}+\mathrm{Mg}^{++}\right)$, the possible $\mathrm{Na}^{+}$percentage is taken as 100 .

Workers at the United States Salinity Laboratory at Riverside, California, have developed a method of predicting the ultimate equilibrium exchangeable sodium percentage (ESP) that will result from the prolonged use of a given irrigation water (Richards, 1954). They define the sodium absorption ratio (SAR) of the water as:

$$
\mathrm{SAR}=\frac{\mathrm{Na}^{+}}{\sqrt{\frac{\mathrm{Ca}^{++}+\mathrm{Mg}^{++}}{2}}}
$$

(cation concentrations in m.e./l). With the value of SAR known, an empirical nomogram may be used to obtain the equilibrium ESP.

The present paper reports the results of some lysimeter experiments designed to determine the effects on soil of irrigation waters containing various proportions of $\mathrm{Na}^{+}$and $\mathrm{CA}^{++}$and of $\mathrm{Cl}^{-}$and $\mathrm{HCO}_{3}^{-}$.

\section{MATERIALS AND METHODS}

The lysimeters consisted of thirty-six 32-gallon, galvanized steel containers (fig. 1) packed (with water) to a depth of 2 feet with thoroughly mixed, Columbia very fine sandy loam. An analysis of the soil appears in table 1 . Drainage was provided for, and leachates were collected at the bottoms of the containers. All containers were surrounded by a soil buffer (see fig. 1).

Nine synthetic irrigation waters were applied in fourfold replication to a total of 36 lysimeters. All waters had a total salt concentration of 10 m.e. per liter. Their compositions are given in table 2 .

In March, 1953, the lysimeters were seeded to alfalfa, and the crop was established by irrigation with tap water. Irrigation with the synthetic waters began in July, 1953, and continued until September, 1957. Water was applied whenever the plants showed signs of wilt, and the same amount of water was applied to each tank with each irrigation. The irrigations were so conducted that, in each case, approximately 10 per cent of the applied water passed through the soil and was collected in a pan at the bottom of the

TABLE 1

ANALYSIS OF COLUMBIA VERY FINE SANDY LOAM USED IN LYSIMETER EXPERIMENT*

\begin{tabular}{|c|c|c|c|c|c|c|c|c|c|c|}
\hline \multicolumn{7}{|c|}{ Water-soluble ions } & \multicolumn{4}{|c|}{ Exchangeable cations } \\
\hline $\mathrm{Ca}^{++}$ & $\mathbf{M g}^{++}$ & $\mathrm{Na}^{+}$ & $\mathrm{K}^{+}$ & $\mathrm{CO}_{3}=$ & $\mathrm{HCO}_{3}^{-}$ & $\mathrm{Cl}^{-}$ & $\mathrm{Ca}^{++}$ & $\mathbf{M g}^{+}$ & $\mathbf{K}^{+}$ & $\mathrm{Na}^{+}$ \\
\hline \multicolumn{7}{|c|}{ m.e. per liter of saturation extract } & \multicolumn{4}{|c|}{ m.e./100 gm. } \\
\hline 1.25 & 0.86 & 0.73 & 0.045 & $\cdots$ & 0.091 & 0.88 & 10.7 & 3.9 & 0.15 & 0.11 \\
\hline
\end{tabular}

* Saturation moisture percentage, $44 ; \mathrm{pH}$ of saturation extract, 6.7 ; conductivity of saturation extract, 0.29 $\mathrm{mmho} / \mathrm{cm}$ at $25^{\circ} \mathrm{C}$; cation exchange capacity, $13.1 \mathrm{~m} . \mathrm{e} . / 100 \mathrm{gm}$. 


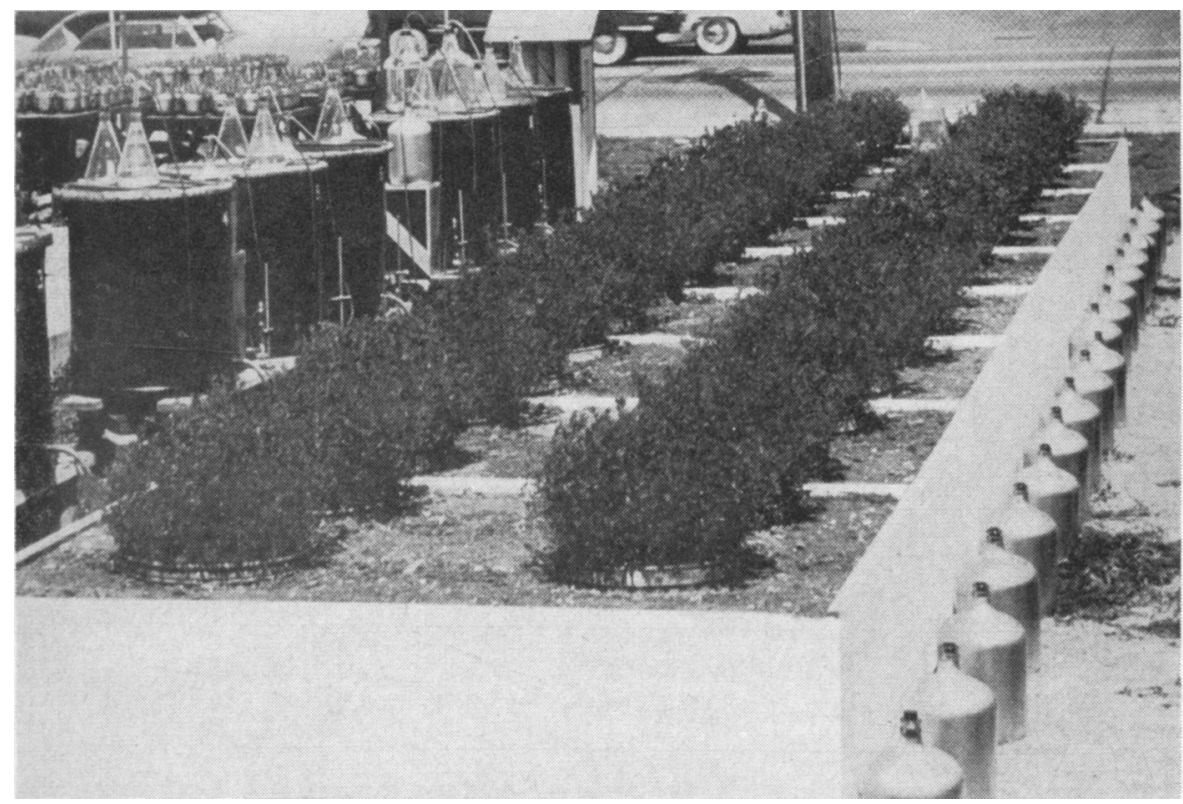

Fig. 1. Lysimeter installation and tanks containing the irrigation waters.

lysimeter. During periods of rain, the soils were protected by suitable covers. Because a preliminary investigation indicated that the soil was phosphatedeficient, $\left(\mathrm{NH}_{4}\right) \mathrm{H}_{2} \mathrm{PO}_{4}$ was applied from time to time. Over the whole period of the experiment, the total $\left(\mathrm{NH}_{4}\right) \mathrm{H}_{2} \mathrm{PO}_{4}$ applied was at the rate of 1,836 pounds per acre. As the tanks were cropped, yield data were obtained, some of which are shown in table 5 .

In September, 1957, soil samples were taken at depths of from 0 to 6 inches, 6 to 18 inches, and 18 to 24 inches. They were air dried, and ground

TABLE 2

COMPOSITION OF APPLIED IRRIGATION WATERS*

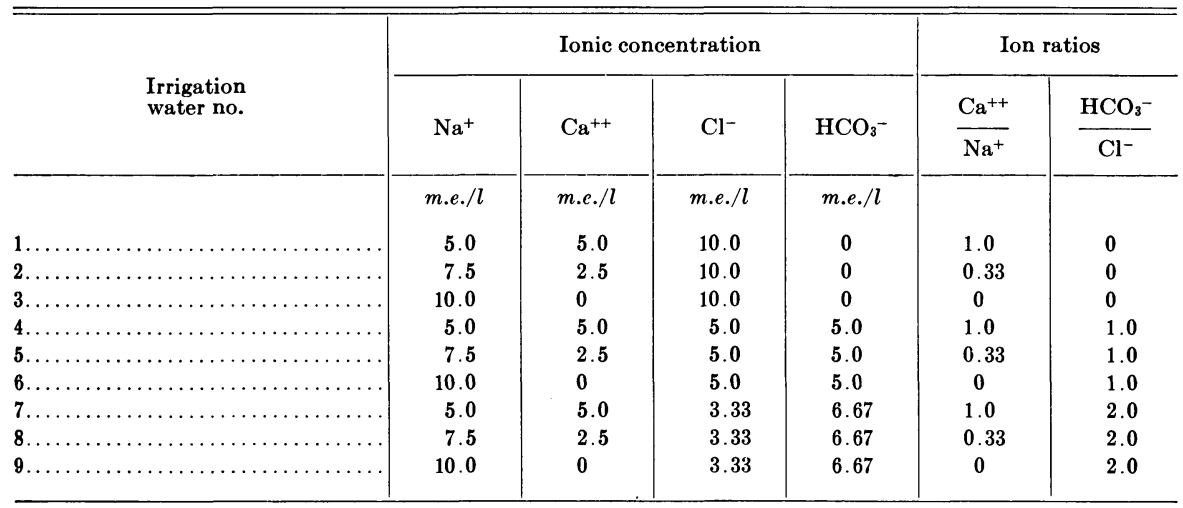

* All waters contained a total of 10 m.e. per liter of salt. 


\begin{tabular}{|c|c|c|c|c|c|c|c|c|c|c|c|}
\hline & 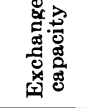 & 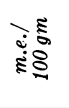 & 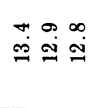 & 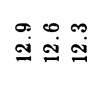 & 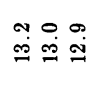 & 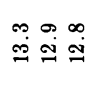 & 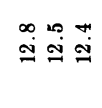 & 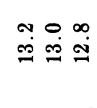 & 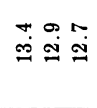 & 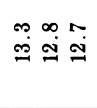 & 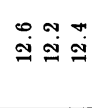 \\
\hline 参 & 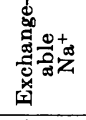 & 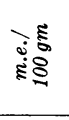 & 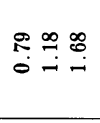 & 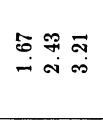 & 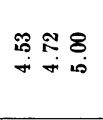 & 蛋 & 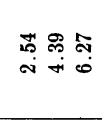 & 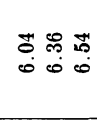 & 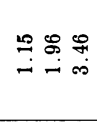 & 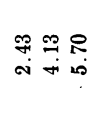 & 8 \\
\hline 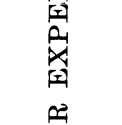 & 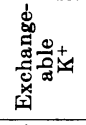 & 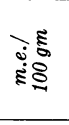 & $\begin{array}{l}2=0 \\
0=0\end{array}$ & $\begin{array}{l} \pm 90 \\
000 \\
00\end{array}$ & $\begin{array}{l}98=7 \\
0 \\
0\end{array}$ & 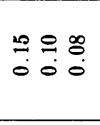 & $\begin{array}{l}9=0 \\
0=0\end{array}$ & \begin{tabular}{l}
92 \\
\hdashline 0 \\
0
\end{tabular} & & $\begin{array}{l}0.80 \\
0: 0 \\
0\end{array}$ & 고 \\
\hline 国 & 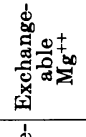 & 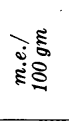 & 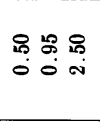 & 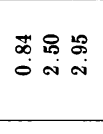 & 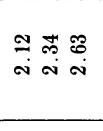 & 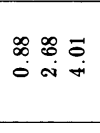 & 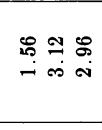 & 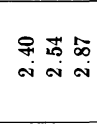 & & & 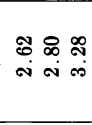 \\
\hline $\begin{array}{l}\text { 孛 } \\
\text { 乐 }\end{array}$ & 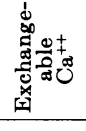 & 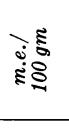 & $\begin{array}{l}0 \\
\dddot{y} \\
=\end{array}$ & $\begin{array}{l}\sim \infty \\
\stackrel{\infty}{\infty}= \\
=\infty \infty\end{array}$ & $\begin{array}{l}\bar{\infty} \\
0 \\
0\end{array}$ & 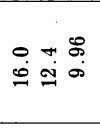 & 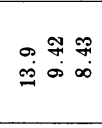 & 芯怘 & 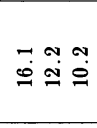 & 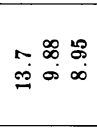 & 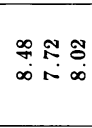 \\
\hline 告 & 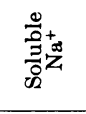 & & $\begin{array}{lll}\infty & 0 \\
0 & 0 & 0 \\
0 & 0\end{array}$ & 邑 & 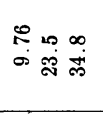 & 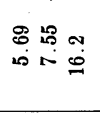 & $\begin{array}{l}N \\
\end{array} \stackrel{0}{=} \stackrel{0}{9}$ & 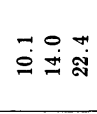 & 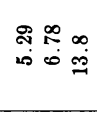 & 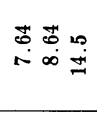 & $\begin{array}{l}0 \\
0 \\
0\end{array}$ \\
\hline 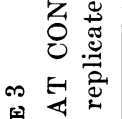 & 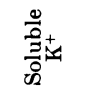 & 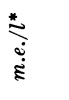 & 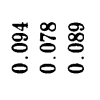 & $\begin{array}{l}\text { 范 } 000 \\
000 \\
000\end{array}$ & 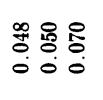 & 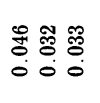 & $\begin{array}{l}\overrightarrow{8} \text { 芯 } \\
00 \\
000\end{array}$ & 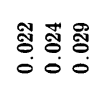 & 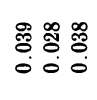 & 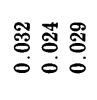 & 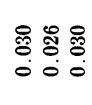 \\
\hline 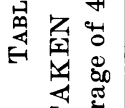 & 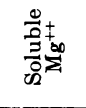 & $\stackrel{*}{\stackrel{*}{*}}$ & 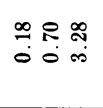 & 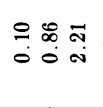 & 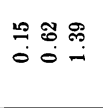 & $\begin{array}{l}0.58 \\
000 \\
000\end{array}$ & 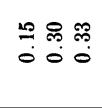 & 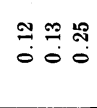 & 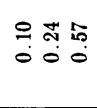 & 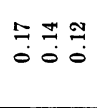 & 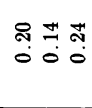 \\
\hline 员岕 & 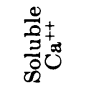 & 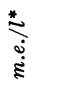 & 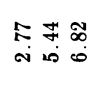 & 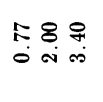 & 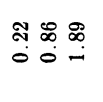 & 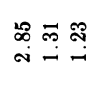 & 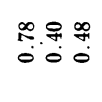 & $\begin{array}{ccc}\Re 0 & \infty & \infty \\
0 & 0 \\
0 & 0 & 0 \\
0\end{array}$ & 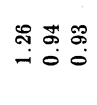 & $\begin{array}{lll}\infty & \pi & \text { भ } \\
0 & 0 & 0\end{array}$ & 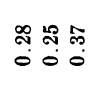 \\
\hline $\begin{array}{l}\text { 崩 } \\
\text { 日 }\end{array}$ & 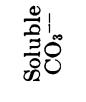 & 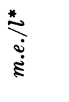 & $\begin{array}{l}88.8 \\
000 \\
00\end{array}$ & $\begin{array}{l}88: 8 \\
000\end{array}$ & $\begin{array}{l}88.8 \\
0 ! 0 \\
0\end{array}$ & $\begin{array}{l}88 \\
0.8 \\
000\end{array}$ & $\begin{array}{l}888 \\
0.0 \\
00\end{array}$ & $\begin{array}{l}888 \\
0.8 \\
00\end{array}$ & $\begin{array}{l}888 \\
0.0 \\
00\end{array}$ & 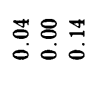 & $\begin{array}{l}880 \\
00 \\
00\end{array}$ \\
\hline 5 & 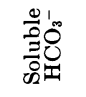 & & 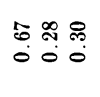 & ț & 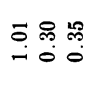 & 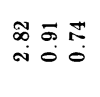 & 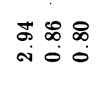 & 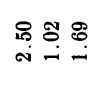 & 点苞 & $\begin{array}{l}8 . \\
\infty \\
\infty\end{array}$ & 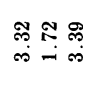 \\
\hline 吾 & 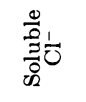 & 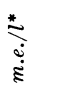 & 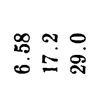 & 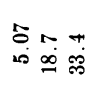 & 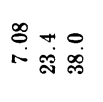 & 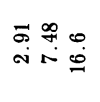 & 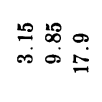 & 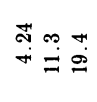 & 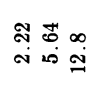 & 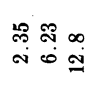 & 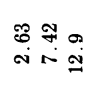 \\
\hline 穵 & $\begin{array}{l}\frac{\pi}{艹 0} \\
\stackrel{0}{0} \\
0\end{array}$ & ્ֻّ & 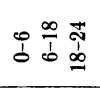 & 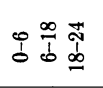 & 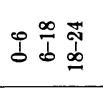 & $\vdots \stackrel{\infty}{b} \underset{0}{\mathbb{1}}$ & 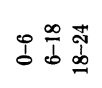 & 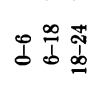 & 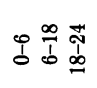 & $\begin{array}{l}0 \\
0 \\
0 \\
0\end{array}$ & @ \\
\hline 至 & 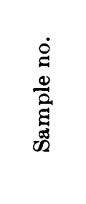 & & & & & & & & & $\begin{array}{ccc}\vdots & \vdots & \vdots \\
\vdots & \vdots & \vdots \\
\infty & \infty & \infty\end{array}$ & \\
\hline
\end{tabular}


to pass a 2-mm sieve. The following determinations were made: $\mathrm{pH}$ and electrical conductivity of the saturation extract; soluble ions in the saturation extract; per cent lime; $\mathrm{NH}_{4} \mathrm{Ac}$-extractable cations ; and the $\mathrm{NH}_{4} \mathrm{Ac}$ exchange capacity. Average results for the four replicates are given in tables

TABLE 4

CHEMICAL ANALYSES OF SOIL SAMPLES TAKEN AT CONCLUSION OF LYSIMETER EXPERIMENT

(Average of 4 replicates)

\begin{tabular}{|c|c|c|c|c|c|c|c|c|c|}
\hline \multirow{2}{*}{$\begin{array}{c}\text { Sample } \\
\text { no. }\end{array}$} & \multirow{2}{*}{ Depth } & \multirow{2}{*}{$\mathrm{pH}^{*}$} & \multirow{2}{*}{$\begin{array}{l}\text { Conduc- } \\
\text { tivity* }\end{array}$} & \multirow{2}{*}{ Line } & \multirow{2}{*}{$\mathrm{SAR}^{*}$} & \multicolumn{2}{|c|}{ ESP } & \multirow{2}{*}{$\begin{array}{l}\text { Sum of } \\
\text { exch. } \\
\text { bases }\end{array}$} & \multirow{2}{*}{$\begin{array}{l}\text { Base } \\
\text { sat. }\end{array}$} \\
\hline & & & & & & est. $\dagger$ & actual & & \\
\hline & inches & & $\mathrm{mmho} / \mathrm{cm}$ & $\% \mathrm{CaCO}_{3}$ & $\sqrt{m m / l}$ & & & m.e. $/ 100 \mathrm{~g}$ & per cent \\
\hline 1.. & $0-6$ & 6.1 & 0.88 & 0.00 & 4.41 & 4.9 & 5.89 & 14.1 & 105 \\
\hline 1.. & $6-18$ & 5.8 & 2.01 & 0.00 & 7.86 & 9.1 & 9.13 & 13.7 & 106 \\
\hline $1 \ldots$ & $.18-24$ & 6.1 & 3.23 & 0.00 & 11.6 & 14 & 13.1 & 14.3 & 111 \\
\hline 2. & $0-6$ & 6.3 & 0.74 & 0.00 & 9.66 & 11 & 12.9 & 13.8 & 107 \\
\hline $2 \ldots$ & $6-18$ & 6.0 & 2.19 & 0.00 & 13.7 & 16 & 19.2 & 13.8 & 110 \\
\hline $2 \ldots$ & $18-24$ & 6.2 & 3.57 & 0.00 & 18.1 & 20 & 26.1 & 14.4 & 118 \\
\hline 3. & $0-6$ & 6.7 & 1.08 & 0.00 & 22.7 & 25 & 34.3 & 13.6 & 103 \\
\hline 3.. & $6-18$ & 6.4 & 2.54 & 0.00 & 35.6 & 34 & 36.3 & 14.2 & 109 \\
\hline $3 .$. & $18-24$ & 6.7 & 3.99 & 0.00 & 27.2 & 28 & 38.9 & 15.2 & 118 \\
\hline $4 \ldots$ & $0-6$ & 7.8 & 0.82 & 0.04 & 4.90 & 5.5 & 8.92 & 18.2 & 137 \\
\hline $4 .$. & $6-18$ & 7.6 & 1.05 & 0.01 & 7.92 & 9.2 & 13.7 & 16.8 & 130 \\
\hline $4 .$. & $18-24$ & 7.6 & 2.04 & 0.01 & 15.7 & 18 & 26.8 & 17.5 & 135 \\
\hline 5. & $0-6$ & 7.9 & 0.82 & 0.01 & 11.3 & 13 & 19.9 & 18.1 & 142 \\
\hline 5. & $6-18$ & 7.7 & 1.34 & 0.00 & 19.6 & 22 & 35.1 & 17.0 & 136 \\
\hline 5. & $18-24$ & 7.8 & 2.23 & 0.01 & 37.0 & 35 & 50.8 & 17.7 & 144 \\
\hline 6. & 0-6 & 7.6 & 1.00 & 0.01 & 21.5 & 23 & 45.7 & 16.6 & 126 \\
\hline 6. & $6-18$ & 7.6 & 1.57 & 0.01 & 29.2 & 29 & 49.0 & 16.6 & 128 \\
\hline 6. & $18-24$ & 8.0 & 2.47 & 0.02 & 34.7 & 33 & 51.2 & 17.3 & 136 \\
\hline 7. & $0-6$ & 7.9 & 0.70 & 0.04 & 5.19 & 6.0 & 8.59 & 18.0 & 135 \\
\hline 7.. & $6-18$ & 7.9 & 0.85 & 0.02 & 8.83 & 10 & 15.2 & 17.0 & 132 \\
\hline $7 \ldots$ & $18-24$ & 8.0 & 1.64 & 0.03 & 15.9 & 18 & 27.2 & 17.7 & 139 \\
\hline 8. & $0-6$ & 8.0 & 0.80 & 0.02 & 10.6 & 12 & 18.2 & $1 \dot{8} .0$ & 136 \\
\hline 8. & $6-18$ & 8.0 & 0.97 & 0.01 & 17.6 & 20 & 32.2 & 17.0 & 133 \\
\hline 8. & $18-24$ & 8.0 & 1.65 & 0.02 & 27.9 & 28 & 44.8 & 17.9 & 141 \\
\hline 9. & $0-6$ & 8.0 & 0.91 & 0.00 & 18.6 & 21 & 48.2 & 17.3 & 138 \\
\hline 9. & $6-18$ & 8.0 & 1.21 & 0.02 & 24.6 & 26 & 53.7 & 17.2 & 140 \\
\hline 9. & $18-24$ & 8.3 & 1.97 & 0.10 & 32.8 & 32 & 58.9 & 18.7 & 151 \\
\hline
\end{tabular}

* Saturation extract, $25^{\circ} \mathrm{C}$.

$\dagger$ From the analyses of the extracts.

3 and 4. The complete chemical data are given in Appendix Table A, pages 166 to 169 .

Sodium and potassium were determined by flame photometry, and $\mathrm{Ca}^{++}$ and $\mathrm{Mg}^{++}$were determined in duplicate by titration with versenate. The saturation water content in all cases was 44 per cent. Lime was determined by the method of Hutchinson and MacLennan (1914), and corrected for soluble $\mathrm{HCO}_{3}{ }^{-}$and $\mathrm{CO}_{3}{ }^{--}$. The values given for exchangeable $\mathrm{Ca}^{++}$have been corrected for the lime dissolved in the extraction with $\mathrm{NH}_{4} \mathrm{Ac}$. (This correction assumes 
that all of the insoluble lime found by the method of Hutchinson and MacLennan dissolves in $\mathrm{NH}_{4} \mathrm{Ac}$. If less lime than this actually dissolved, the values for exchangeable $\mathrm{Ca}^{++}$given are low.) The cation exchange capacity was determined with $\mathrm{NH}_{4} \mathrm{Ac}$ at $\mathrm{pH} 7.0$.

\section{RESULTS AND DISCUSSION}

The analytical results (tables 3 and 4 ) show that the amount of soluble salts increased in all cases and at all depths. The lowest conductivity observed was $0.7 \mathrm{mmho} / \mathrm{cm}$, in contrast to the value of $0.29 \mathrm{mmho} / \mathrm{cm}$ on the original soil. The highest values approached $4 \mathrm{mmho} / \mathrm{cm}$, reflecting a salt content which may be injurious to very sensitive crops. In the field, therefore, greater leaching would apparently be desirable.

As expected, the soluble $\mathrm{Na}^{+}$and $\mathrm{Cl}^{-}$contents increased everywhere over the amounts initially found in the soil since all of the irrigation waters contained $\mathrm{NaCl}$. The soluble $\mathrm{Ca}^{++}$increased where the high $\mathrm{Ca}^{++}$, all-chloride water (treatment 1) was used, but decreased in most of the other treatments. The greatest decrease occurred when the high- $\mathrm{HCO}_{3}{ }^{-}$waters were used. The soluble $\mathrm{Mg}^{++}$decreased in the surface of the soils treated with the $\mathrm{Cl}^{-}$waters, but increased with depth. Wherever water containing $\mathrm{HCO}_{3}{ }^{-}$was used, soluble $\mathrm{Mg}^{++}$decreased throughout the soil profile. The content of $\mathrm{HCO}_{3}{ }^{-}$ions in the soil increased throughout.

The conductivity values (table 4 ) increased with depth in all cases. Similar results were obtained by Harding et al. (1958). This condition was evidently produced by the following processes: The salt carried into the soil by a given irrigation was uniformly distributed with depth to a first appreximation. Because the water loss from the system was primarily via transpiration by the plants, and since the alfalfa roots were distributed throughout the lysimeters, there was probably little salt redistribution as the soils dried. During the next irrigation, the infiltrating water displaced salts downward, and the repetition of this process in the course of many irrigations produced the downward gradients. The distribution is thus quite different from that to be expected if appreciable amounts of water were removed from the surface by evaporation.

The soluble $\mathrm{Na}^{+}$and $\mathrm{Cl}^{-}$contents increased with depth by appreciable factors in all cases, whereas the soluble $\mathrm{Ca}^{++}$increased with depth only when the purely $\mathrm{Cl}^{-}$waters (treatments $1,2,3$ ) were used. In the other cases, soluble $\mathrm{Ca}^{++}$and $\mathrm{HCO}_{3}{ }^{-}$decreased with depth. No general pattern of soluble $\mathrm{Ca}^{++}$distribution emerged where $\mathrm{HCO}_{3}{ }^{-}$waters were applied. The soluble $\mathrm{Mg}^{++}$increased with depth following the use of purely $\mathrm{Cl}^{-}$waters, probably as a result of the exchange of $\mathrm{Mg}^{++}$from the soil and its downward displacement. Where waters containing $\mathrm{HCO}_{3}{ }^{-}$were used, the soluble $\mathrm{Mg}^{++}$either increased much less rapidly with depth or actually decreased.

In all cases, the exchangeable $\mathrm{Na}^{+}$content increased over the amount initially present in the soil. As expected, the increases were greatest when $\mathrm{Ca}^{++}$ was not added to the irrigation water (treatments $3,6,9$ ). The highest exchangeable $\mathrm{Na}^{+}$percentages were produced when $\mathrm{HCO}_{3}^{-}$was added. For a given level of $\mathrm{HCO}_{3}{ }^{-}$concentration, decreasing $\mathrm{Ca}^{++}$in the irrigation water 
resulted in an increase in exchangeable $\mathrm{Na}^{+}$in the soil. However, for a given cation ratio in the irrigation water, the amount of exchangeable $\mathrm{Na}^{+}$produced does not appear closely related to the amount of $\mathrm{HCO}_{3}{ }^{-}$in the water (compare treatments 2,5 , and 8 , for example). This is in contrast to what might be expected from Eaton's (1950) principle. It is of further interest that the $\mathrm{CaCO}_{3}$ analyses do not reflect levels that bear any relationship to the amounts of exchangeable $\mathrm{Na}^{+}$produced. (To see this, 0.01 per cent lime $\approx 0.20$ m.e. $/ 100 \mathrm{gm}$ of soil.) The failure of $\mathrm{CaCO}_{3}$ to precipitate was probably the result of the high $\mathrm{CO}_{2}$ partial pressure caused by root respiration. (It is of interest in this connection that, in many instances, $\mathrm{CaCO}_{3}$ was observed to precipitate in the leachates after a short period of standing in the pans.)

The amounts of exchangeable $\mathrm{Ca}^{++}$tended to increase when the irrigation waters were high in $\mathrm{Ca}^{++}$(treatments $1,4,7$ ), and decreased when $\mathrm{Ca}^{++}$was absent (treatments 3,6,9). Again, these changes appear to be more closely related to the cation ratio than to the anion composition of the irrigation water. In fact, when waters of comparable cation ratios were used, a greater exchangeable $\mathrm{Ca}^{++}$resulted in the case of water high in $\mathrm{HCO}_{3}{ }^{-}$(treatment 7) than in the case of the purely $\mathrm{Cl}^{-}$water (treatment 1 ). This was also true when $\mathrm{Ca}^{++}$was not added to the water (compare treatments 3 and 9 ). These results also are not consistent with Eaton's (1950) principle.

As expected from the fact that $\mathrm{Mg}^{++}$was absent in the irrigation waters, the exchangeable $\mathrm{Mg}^{++}$of the soils was generally decreased by exchange and leaching. Exchangeable $\mathrm{K}^{+}$was either essentially unchanged or decreased.

As with the soluble constituents, appreciable increases occurred in the exchangeable $\mathrm{Na}^{+}$content with depth. These gradients were weakest where purely $\mathrm{Na}^{+}$, waters were applied (treatments $3,6,9$ ). These results are contrary to what would be expected from ion-exchange chromatographic effects which are thought to occur when $\mathrm{Na}^{+}$-bearing waters are applied to a $\mathrm{Ca}^{++}$dominated soil. The explanation is apparently connected with the well-known "cation-dilution effect" (for example, see Reitemeier [1946]). According to this principle, when a soil containing $\mathrm{Ca}^{++}$and $\mathrm{Na}^{+}$ions is diluted, some exchangeable $\mathrm{Na}^{+}$is replaced on the exchange complex by $\mathrm{Ca}^{++}$. The exchangeable $\mathrm{Na}^{+}$thus decreases on dilution, and there is an increase in the exchangeable $\mathrm{Ca}^{++}$. The increases in exchangeable $\mathrm{Na}^{+}$with depth observed in the lysimeters presumably resulted from a reversal of this process. The salt concentration increases with depth, as a result of the mechanism described above, and produces increasing exchangeable $\mathrm{Na}^{+}$contents.

The values of the SAR determined on the saturation extracts are given in table 4 together with the values of the ESP predicted from the nomogram used by the Salinity Laboratory. At low values of ESP, the predicted values agree well with those obtained experimentally, but serious discrepancies appear when the ESP is high. This may be connected with the apparent excess base saturation indicated in table 4 and discussed further below.

The exchangeable $\mathrm{Ca}^{++}$content of the soil decreased appreciably with depth except where purely $\mathrm{Na}^{+}$waters were applied (treatments $3,6,9$ ). It is in just such cases as the latter that the greatest decreases would be ex- 
pected on the basis of chromatographic effects, again illustrating the significance of the salt-movement mechanism and cation-dilution principle discussed above.

It has been emphasized that the increases in exchangeable $\mathrm{Na}^{+}$and decreases in exchangeable $\mathrm{Ca}^{++}$occurring in this soil were not the result of $\mathrm{CaCO}_{3}$ precipitation. It is interesting to note that wherever the application of $\mathrm{HCO}_{3}^{-}$waters produced an increase in exchangeable $\mathrm{Na}^{+}$, an apparent excess base saturation was also encountered. Excess base saturation, for which several explanations are possible, has been noted in neutral and alkaline soils for many years. The fixation of $\mathrm{NH}_{4}{ }^{+}$during the exchange-capacity determination would lead to apparent excess saturation, but this is clearly not the explanation in the present case since the $\mathrm{NH}_{4} \mathrm{Ac}$ exchange capacities are essentially independent of the treatments. It has been pointed out that leaching soils having a high $\mathrm{pH}$ with $\mathrm{NH}_{4} \mathrm{Ac}$ at $\mathrm{pH} 7.0$ will increase the amounts of exchangeable hydrogen held and therefore introduce a discrepancy between the bases extracted and the $\mathrm{NH}_{4} \mathrm{Ac}$ exchange capacity. It is difficult, however, to imagine that the Columbia soil used in this experiment would be 25 per cent $\mathrm{H}^{+}$saturated at $\mathrm{pH}$ 7.0. (Additional evidence to be reported elsewhere supports this view.) The chelation of $\mathrm{Ca}^{++}$or $\mathrm{Mg}^{++}$ by soil organic matter may account for excess saturation, but independent evidence not presented here indicates that such effects will not account for the magnitude of excess saturation encountered. On the basis of their experimental evidence, Bower and Truog (1940) have postulated that, in neutral soils, calcium and magnesium can be adsorbed as the ion species $(\mathrm{CaOH})^{+}$ and $(\mathrm{MgOH})^{+}$. The data obtained in this experiment are consistent with the assumption that such ion species account for an apparent excess cation adsorption. If this is the case, $(\mathrm{CaOH})^{+}$and $(\mathrm{MgOH})^{+}$must be much more strongly adsorbed than are $\mathrm{Ca}^{++}$and $\mathrm{Mg}^{++}$. For example, Harned and Owen (1950) give the following value for the dissociation constant of $(\mathrm{CaOH})^{+}$:

$$
\frac{\left(\mathrm{Ca}^{++}\right)\left(\mathrm{OH}^{-}\right)}{(\mathrm{CaOH})^{+}}=3.1 \times 10^{-2}
$$

Thus, in solution at $\mathrm{pH} 8.0$, the ratio $\frac{\mathrm{Ca}^{++}}{(\mathrm{CaOH})^{+}}$has the value of $3.1 \times 10^{4}$; yet at this $\mathrm{pH}$, appreciable excess cation adsorption is noted, indicating that very significant amounts of $(\mathrm{CaOH})^{+}$may be adsorbed.

Where the amounts of applied $\mathrm{HCO}_{3}{ }^{-}$are equal to or greater than the amounts of $\mathrm{Cl}^{-}$applied, comparable degrees of accumlation of the two ions would be expected. The $\mathrm{Cl}^{-}$accumulation, however, is much more marked. This disappearance of $\mathrm{HCO}_{3}{ }^{-}$possibly indicates that $(\mathrm{CaOH})^{+}$is formed by the following reaction:

$$
\mathrm{H}_{2} \mathrm{O}+\mathrm{Ca}^{++}+\mathrm{HCO}_{3}^{-}=(\mathrm{CaOH})^{+}+\mathrm{H}_{2} \mathrm{CO}_{3}
$$

$\mathrm{CO}_{2}$ would then be lost from the system through the dissolution of $\mathrm{H}_{2} \mathrm{CO}_{3}$ to $\mathrm{CO}_{2}$ and $\mathrm{H}_{2} \mathrm{O}$. The equilibrium for this reaction would lie to the right since the $(\mathrm{CaOH})^{+}$formed is adsorbed. 
It is of interest to note that wherever $\mathrm{HCO}_{3}{ }^{-}$waters were applied, the $\mathrm{pH}$ and degree of excess cation adsorption did not show much change, either with the water used or with depth. The constancy of the $\mathrm{pH}$ probably results from the fact that where the exchangeable $\mathrm{Na}^{+}$is high, the salt concentration is also high, and there is a repression of the hydrolysis of $\mathrm{Na}^{+}$. The absence of depth gradients in excess base saturation conceivably reflects the fact that, where exchangeable $\mathrm{Ca}^{++}$decreases appreciably with depth, exchangeable $\mathrm{Mg}^{++}$increases. It is expected that the $(\mathrm{MgOH})^{+}$complex would be less dissociated than the $(\mathrm{CaOH})^{+}$.

The data on total yields (table 5) appear to indicate significant differences among the treatments. These differences, however, are actually the result of

TABLE 5

TOTAL YIELD OF ALFALFA PER LYSIMETER, AND

YIELDS FOR TWO HARVESTS

(Average of 4 replicates)

\begin{tabular}{|c|c|c|c|}
\hline \multirow{2}{*}{ Treatment no. } & \multirow{2}{*}{$\begin{array}{c}\text { Total yield } \\
\text { per lysimeter }\end{array}$} & \multicolumn{2}{|c|}{ Average yield per lysimeter } \\
\hline & & $\begin{array}{c}\text { Harvested } \\
\text { Dec. 6, } 1955\end{array}$ & $\begin{array}{l}\text { Harvested } \\
\text { June 21, } 1956\end{array}$ \\
\hline & $g m d r y w t$ & $g m d r y w t$ & $g m d r y w t$ \\
\hline $1 \ldots \ldots \ldots \ldots \ldots \ldots \ldots$ & 1,870 & 34.8 & 184 \\
\hline $2 \ldots \ldots \ldots \ldots \ldots \ldots \ldots$ & 1,957 & 38.0 & 183 \\
\hline $3 \ldots \ldots \ldots$ & 1,984 & 41.5 & 165 \\
\hline $4 \ldots$ & 2,176 & 48.5 & 198 \\
\hline $5 \ldots$ & 2,255 & 52.0 & 199 \\
\hline $6 \ldots \ldots$ & 2,351 & 50.0 & 182 \\
\hline $7 \ldots \ldots \ldots$ & 2,214 & 50.2 & 188 \\
\hline $8 \ldots$ & 2,231 & 51.5 & 184 \\
\hline $9 \ldots \ldots$ & 2,405 & 55.8 & 184 \\
\hline
\end{tabular}

fertility problems induced by the treatments. The harvest of December 6 , 1955 , for example, shows the greatest yields in the tanks containing the highest exchangeable $\mathrm{Na}^{+}$content. These apparently anomalous results do not appear in the harvest of June 21, 1956, which was made following a fertilization with $\mathrm{NH}_{4}\left(\mathrm{H}_{2} \mathrm{PO}_{4}\right)$.

Examples of the leachate data obtained are given in table 6 . During the course of the experiment, the ratio of $\mathrm{Ca}^{++}+\mathrm{Mg}^{++}$to $\mathrm{Na}^{+}$in the leachates dropped from very high values to values below that of the applied water in eases where $\mathrm{HCO}_{3}{ }^{-}$was present. This possibly reflects the formation and adsorption of $(\mathrm{CaOH})^{+}$in the soil.

In summary, the results of the experiment show that the application of $\mathrm{HCO}_{3}{ }^{-}$-bearing waters results in an increase in exchangeable $\mathrm{Na}^{+}$content and the production of apparently excess cation adsorption. Following a cropping regime, the soluble salts and exchangeable $\mathrm{Na}^{+}$were found to increase markedly with depth. The mechanism of exchangeable $\mathrm{Na}^{+}$production involves the cation dilution effect and possibly the production of $(\mathrm{CaOH})^{+}$and $(\mathrm{MgOH})^{+}$, rather than $\mathrm{CaCO}_{3}$ precipitation, at least under the conditions of 
this experiment. Thus, the estimation of the exchangeable sodium percentage in equilibrium with a given irrigation water, based on exchange equations or on Eaton's (1950) principle, may not serve to predict field behavior when a crop is grown. Furthermore, the presence of a crop may reverse expected chromatographic effects.

\section{TABLE 6}

VOLUME OF LEACHATE RECOVERED FROM LYSIMETERS, AND ANALYSES OF LEACHATES OF JANUARY 10, 1954, AND JUNE 10, 1956

(Average of 4 replicates)

\begin{tabular}{|c|c|c|c|c|c|c|}
\hline \multirow[t]{2}{*}{ Treatment no. } & \multirow{2}{*}{$\begin{array}{c}\text { Total volume } \\
\text { irrigation } \\
\text { water applied }\end{array}$} & \multicolumn{2}{|c|}{ Total leach recovered } & \multicolumn{3}{|c|}{$\begin{array}{l}\text { Cation ratio } \\
\frac{\mathrm{Ca}^{++}+\mathrm{Mg}^{++}}{\mathrm{Na}^{+}}\end{array}$} \\
\hline & & & & $\begin{array}{l}\text { in } \mathrm{H}_{2} \mathrm{O} \\
\text { applied }\end{array}$ & $\begin{array}{c}\text { leachate } \\
1 / 10 / 54\end{array}$ & $\begin{array}{c}\text { leachate } \\
6 / 10 / 56\end{array}$ \\
\hline & liters & liters & $\begin{array}{c}\text { per cent } \\
\text { of applied }\end{array}$ & & & \\
\hline 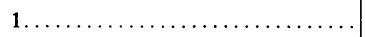 & $1,664^{*}$ & 202 & 12.1 & 1.0 & 15.0 & 1.33 \\
\hline $2 \ldots \ldots \ldots \ldots \ldots \ldots$ & 1,664 & 189 & 11.4 & 0.30 & 12.9 & 0.53 \\
\hline $3 \ldots \ldots \ldots \ldots \ldots$ & 1,664 & 173 & 10.4 & $\mathbf{0}$ & 10.0 & 0.21 \\
\hline $4 \ldots \ldots$ & 1,664 & 128 & 7.74 & 1.0 & 24.9 & 0.44 \\
\hline $5 \ldots \ldots$ & 1,664 & 132 & 7.98 & 0.30 & 14.2 & 0.18 \\
\hline $6 \ldots \ldots$ & 1,664 & 129 & 7.80 & 0 & 12.8 & 0.10 \\
\hline $7 \ldots \ldots$ & 1,664 & 138 & 8.34 & 1.0 & 16.9 & 0.24 \\
\hline $8 \ldots \ldots$ & 1,664 & 147 & 8.90 & 0.30 & 8.78 & 0.11 \\
\hline $9 \ldots \ldots \ldots \ldots \ldots$ & 1,664 & 137 & 8.30 & 0 & 16.4 & 0.08 \\
\hline
\end{tabular}

- With the lysimeters used. this amount of water corresponded to 30.2 feet. 
Appendix Table A begins on the following page. 


\begin{tabular}{|c|c|c|c|c|c|c|c|c|}
\hline & 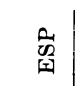 & & 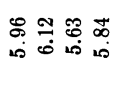 & 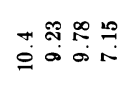 & 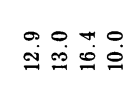 & 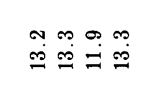 & 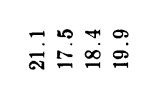 & $\begin{array}{l}-10 \\
\dot{8}: 0\end{array}$ \\
\hline 学 & : & 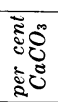 & $\begin{array}{l}8888 \\
0000\end{array}$ & $\begin{array}{l}5888 \\
0000 \\
000\end{array}$ & $\begin{array}{l}8880 \\
0000\end{array}$ & $\begin{array}{l}8888 \\
0000\end{array}$ & $\begin{array}{l}8808 \\
0000\end{array}$ & $\begin{array}{l}8.8 \\
00\end{array}$ \\
\hline $\begin{array}{l}\frac{1}{x} \\
\frac{1}{2} \\
2\end{array}$ & 总声 & है & 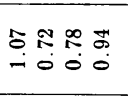 & 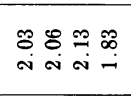 & 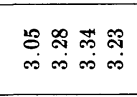 & 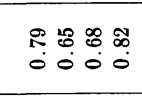 & 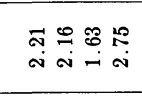 & 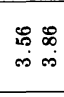 \\
\hline 国 & 壳 & & 웅 ๆ & تُ & 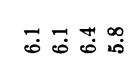 & 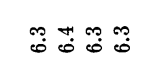 & 我 & $\overrightarrow{0}+\overrightarrow{0}$ \\
\hline 㢄 & 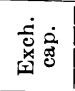 & 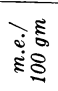 & 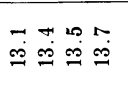 & 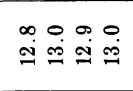 & 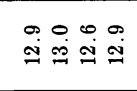 & 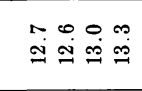 & 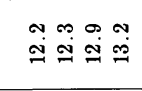 & $\stackrel{\circ}{9} \stackrel{\circ}{=}$ \\
\hline 言 & 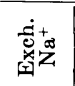 & $\begin{array}{l}\text { हू } \\
\text { हू }\end{array}$ & 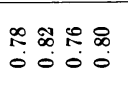 & ஜ్ต & 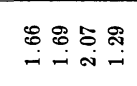 & 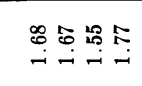 & 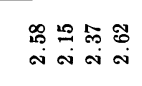 & 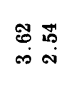 \\
\hline 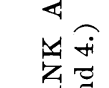 & 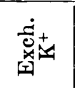 & 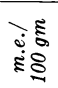 & $\begin{array}{l}\because 2 \\
0 \\
0\end{array}$ & $\begin{array}{l}0=\cong= \\
0000\end{array}$ & $\begin{array}{l}90.8=1 \\
0000 \\
000\end{array}$ & $\frac{\pi}{0}=\frac{\pi}{0}=\frac{\pi}{0}$ & 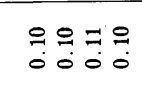 & $\begin{array}{l}0 \\
0 \\
0\end{array}$ \\
\hline 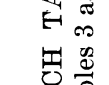 & 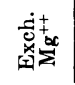 & 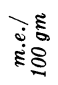 & 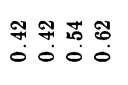 & 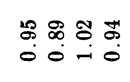 & 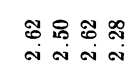 & & 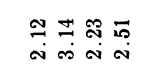 & $\begin{array}{l}\text { No } \\
\text { 에 }\end{array}$ \\
\hline 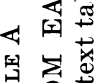 & 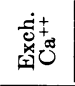 & 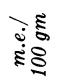 & 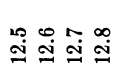 & 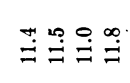 & 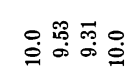 & 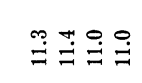 & 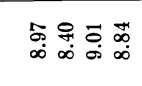 & $\underset{\infty}{\infty} \underset{\infty}{\infty} \underset{\infty}{\infty}$ \\
\hline 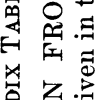 & 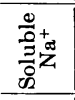 & 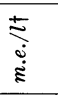 & 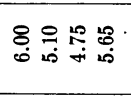 & $\stackrel{\infty}{=} \stackrel{0}{=} \stackrel{0}{\Xi} \stackrel{0}{g}$ & 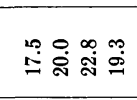 & جి & 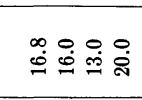 & 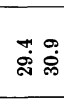 \\
\hline 我事 & 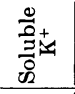 & 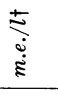 & 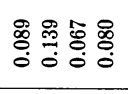 & 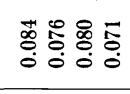 & 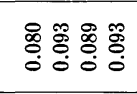 & 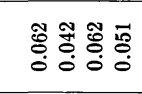 & 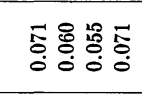 & $\begin{array}{l}0 \\
0 \% \\
0 \\
0 \\
0\end{array}$ \\
\hline 趽营 & 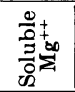 & 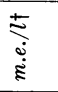 & 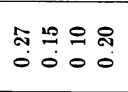 & 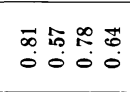 & 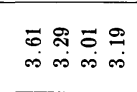 & $\begin{array}{lll}0 & 0 \\
0 & 0 & 0 \\
0 & 0 & 0 \\
0\end{array}$ & 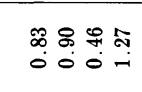 & 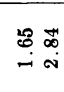 \\
\hline 恼离 & 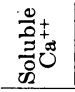 & 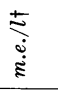 & 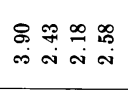 & 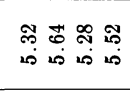 & 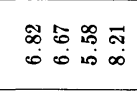 & 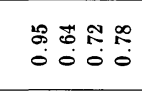 & 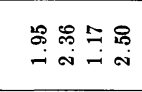 & 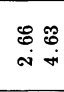 \\
\hline 最 & \begin{tabular}{l|l} 
& 0 \\
0 & 1 \\
0 & 0 \\
0 & 0 \\
0 & 0 \\
0
\end{tabular} & 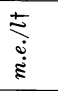 & $\begin{array}{l}888 \\
000 \\
000\end{array}$ & $\begin{array}{l}88.88 \\
0000\end{array}$ & $\begin{array}{l}88.88 \\
0000\end{array}$ & $\begin{array}{l}8888 \\
0000\end{array}$ & $\begin{array}{l}8888 \\
0000\end{array}$ & $\begin{array}{l}8: 8 \\
00\end{array}$ \\
\hline $\begin{array}{l}\frac{5}{0} \\
02 \\
\text { 至 }\end{array}$ & 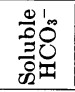 & 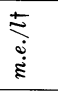 & 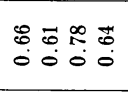 & 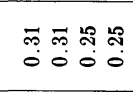 & 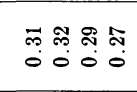 & 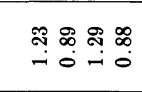 & 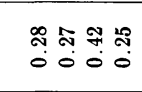 & $\stackrel{\substack{0 \\
0}}{0}$ \\
\hline 岕 & 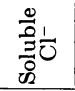 & 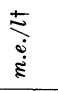 & 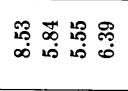 & 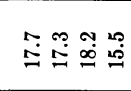 & 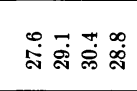 & 驾 & 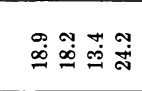 & $\stackrel{\infty}{m}$ \\
\hline 눈 & 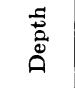 & ङूँ & $\begin{array}{llll}0 & 0 & 0 \\
0 & 0 & 0 & 0\end{array}$ & $\stackrel{\infty}{b} \frac{\infty}{b} \frac{\infty}{b} \frac{\infty}{b}$ & 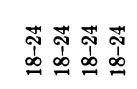 & $\begin{array}{lll}0 & 0 & 0 \\
0 & 0 & 0\end{array}$ & $\overbrace{b}^{\infty} \frac{\infty}{b} \frac{\infty}{b} \frac{\infty}{b}$ & 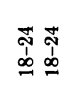 \\
\hline 疍 & 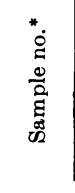 & & $\begin{array}{ccc}\vdots & \vdots & \vdots \\
\vdots & \vdots & \vdots \\
\vdots & \vdots & \vdots \\
\vdots & \vdots & \vdots \\
\end{array}$ & $\begin{array}{ccc}\vdots & \vdots \\
& \vdots & \vdots\end{array}$ & 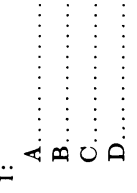 & 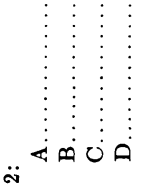 & $\ddot{\sim}^{4}$ & i \\
\hline
\end{tabular}




\begin{tabular}{|c|c|c|c|c|c|c|}
\hline 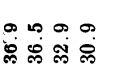 & 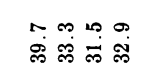 & 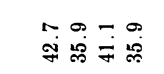 & 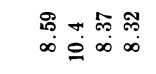 & 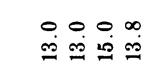 & 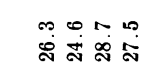 & $\begin{array}{l}\infty \oplus \propto \\
\bar{N}=\bar{N}\end{array}$ \\
\hline $\begin{array}{l}8808 \\
8000 \\
000\end{array}$ & $\begin{array}{llll}8 & 8 & 0 & 0 \\
0 & 0 & 0 & 0\end{array}$ & 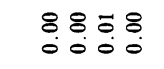 & 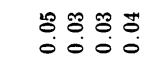 & 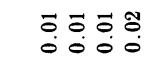 & 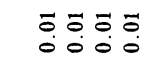 & 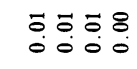 \\
\hline$\cong$ & 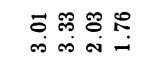 & 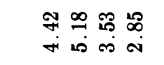 & 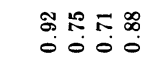 & 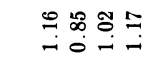 & 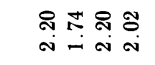 & 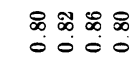 \\
\hline 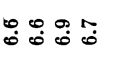 & 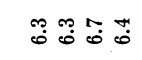 & 둥 & 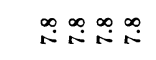 & 怘芯怘 & テさ゚怘 & مِ \\
\hline 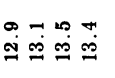 & 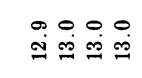 & 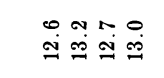 & 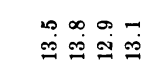 & $\overrightarrow{\ddot{m}}$ & 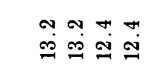 & 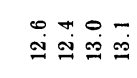 \\
\hline 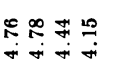 & 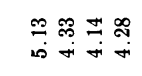 & 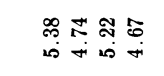 & 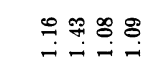 & テペ゚ & 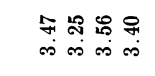 & 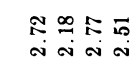 \\
\hline 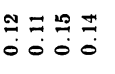 & 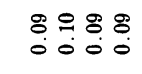 & $\begin{array}{l}\infty 00 \div \frac{1}{0} \\
000\end{array}$ & $\begin{array}{l}\because \dddot{1}=0 \\
000\end{array}$ & $\begin{array}{l}8000 \\
000 \\
000\end{array}$ & 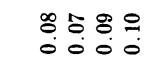 & $=\frac{9}{0} \frac{9}{0}$ \\
\hline 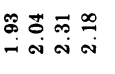 & 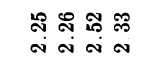 & 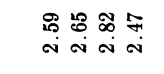 & 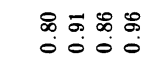 & 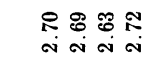 & 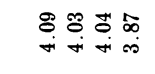 & 尔 \\
\hline 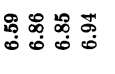 & 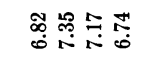 & 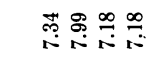 & 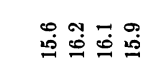 & 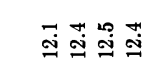 & 官 & مُ مِّ \\
\hline 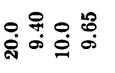 & 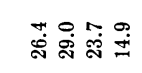 & ம우우 & 유 융ำ & \& & $\begin{array}{l}\mathscr{0} \\
\stackrel{\infty}{\leftrightarrows} \stackrel{\infty}{=} \stackrel{0}{=}\end{array}$ & 象年 \\
\hline 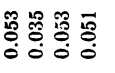 & 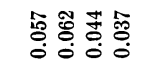 & 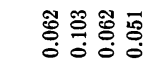 & 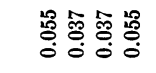 & 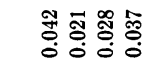 & 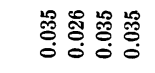 & 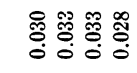 \\
\hline 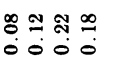 & 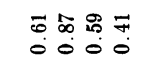 & 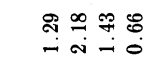 & 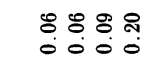 & 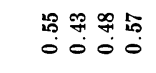 & 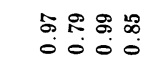 & 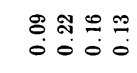 \\
\hline 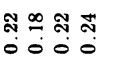 & $\begin{array}{l}\infty \\
0 \\
0 \\
0\end{array}$ & 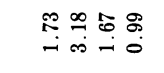 & 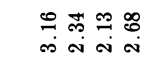 & تُ & 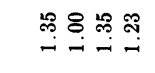 & $\begin{array}{l}\text { 용요 } \\
000\end{array}$ \\
\hline $\begin{array}{l}8888 \\
0000 \\
00\end{array}$ & $\begin{array}{l}8888 \\
0000\end{array}$ & $\begin{array}{l}8880 \\
000 \\
00\end{array}$ & $\begin{array}{l}8889 \\
0000\end{array}$ & $\begin{array}{l}8880 \\
0000\end{array}$ & $\begin{array}{l}8880 \\
000 \\
000\end{array}$ & $\begin{array}{l}88.8 \% \\
00 \\
0\end{array}$ \\
\hline 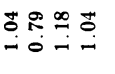 & 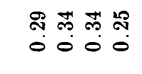 & 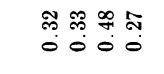 & 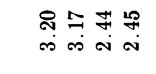 & 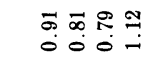 & 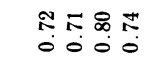 & 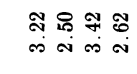 \\
\hline 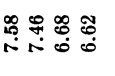 & 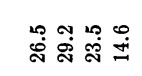 & 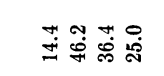 & 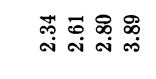 & 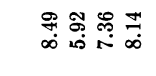 & $\vec{\infty} \stackrel{\oplus}{\rightarrow} \underset{\infty}{\infty}$ & 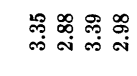 \\
\hline 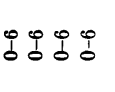 & $\frac{\infty}{1} \frac{\infty}{b} \frac{\infty}{1} \frac{\infty}{b}$ & 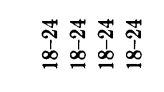 & $\begin{array}{llll}0 & 0 & 0 \\
0 & 1 & 0 & 0\end{array}$ & $\prod_{b}^{\infty} \frac{\infty}{b} \frac{\infty}{b} \frac{\infty}{b}$ & 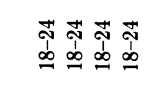 & $\begin{array}{llll}0 & 0 & 0 & 0 \\
1 & 1 & 1 & 0\end{array}$ \\
\hline $\begin{array}{ccc}\vdots & \vdots & \vdots \\
\vdots & \vdots & \vdots \\
\vdots & \vdots & \vdots \\
\vdots & \vdots & \vdots \\
\vdots & \vdots & \vdots \\
\text { ४ } & 0\end{array}$ & 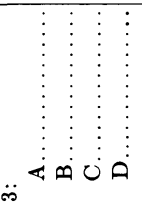 & 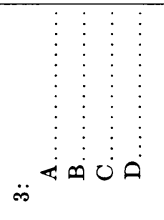 & 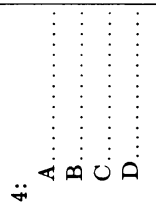 & 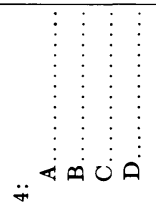 & 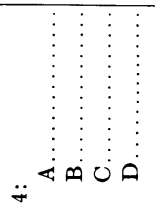 & 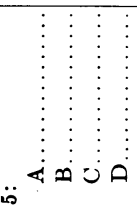 \\
\hline
\end{tabular}




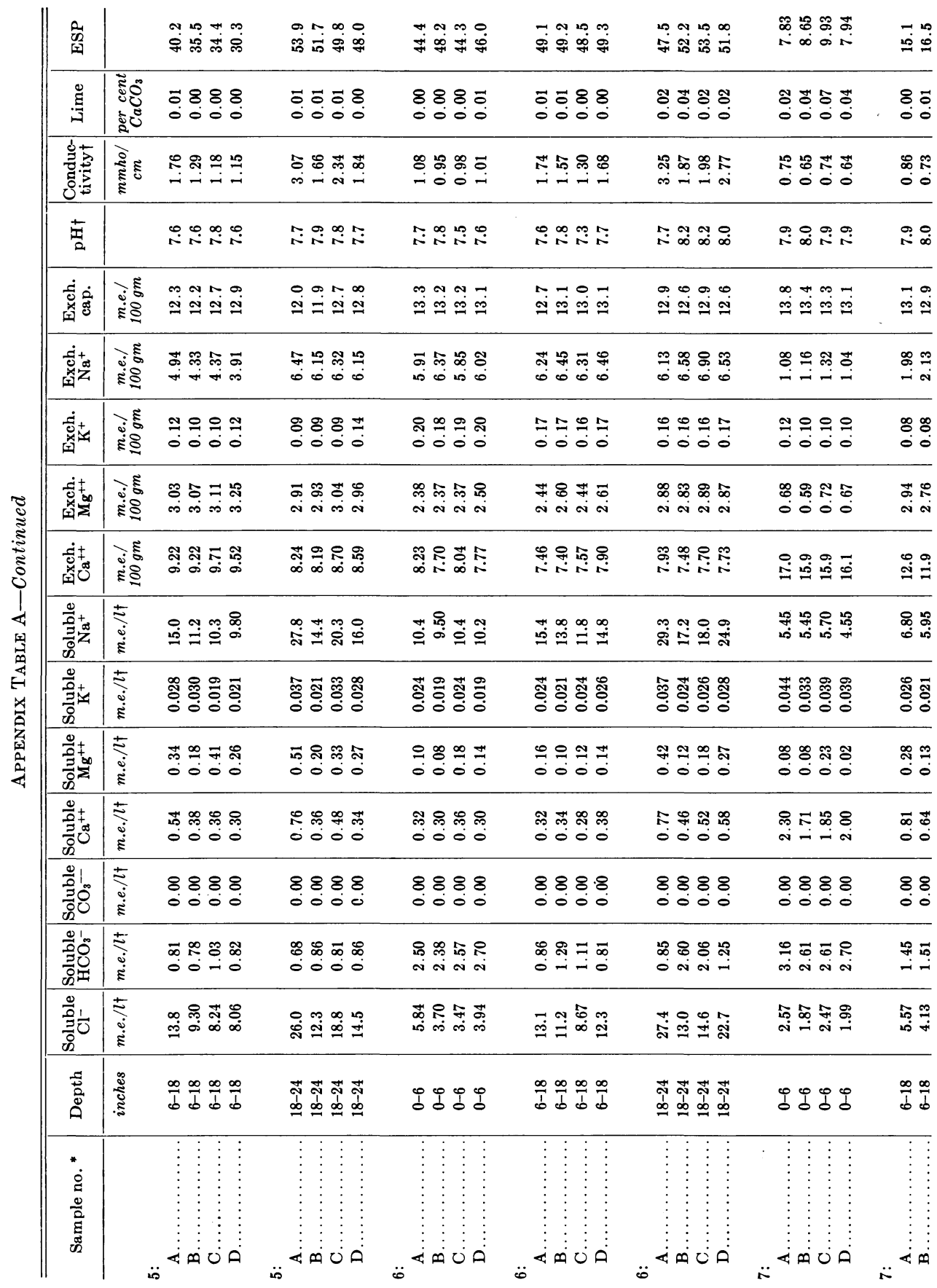




\begin{tabular}{|c|c|c|c|c|c|c|}
\hline 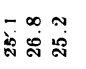 & $\stackrel{\infty}{\infty}=\vec{\Phi}$ & 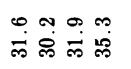 & 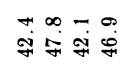 & 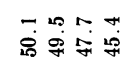 & 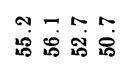 & $\begin{array}{l}\infty \\
0 \\
0 \\
0\end{array}$ \\
\hline 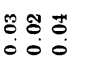 & 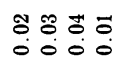 & 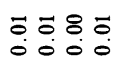 & 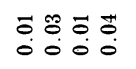 & 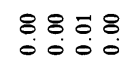 & 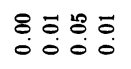 & 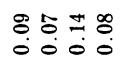 \\
\hline 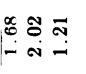 & 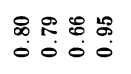 & 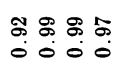 & 尽芯名范 & 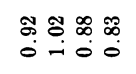 & 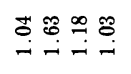 & 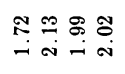 \\
\hline$b_{\infty} \stackrel{\infty}{\stackrel{0}{\infty}} \underset{\infty}{\infty}$ & 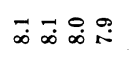 & $\stackrel{\circ}{\infty} \underset{\infty}{\circ} \stackrel{\infty}{i} \stackrel{0}{\infty}$ & 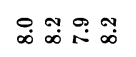 & $\vec{\infty} \underset{\infty}{\circ} \stackrel{\circ}{\infty} \vec{\infty}$ & $\vec{\infty} \underset{\infty}{\vec{\infty}} \vec{\infty}$ & $\underset{\infty}{\infty} \underset{\infty}{\infty} \underset{\infty}{\infty} \underset{\infty}{\infty}$ \\
\hline 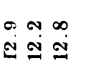 & 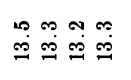 & 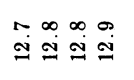 & 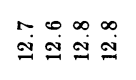 & ذِ & 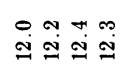 & 象 \\
\hline 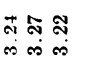 & 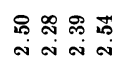 & 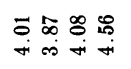 & 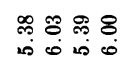 & 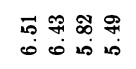 & 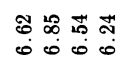 & 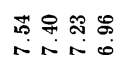 \\
\hline $\begin{array}{l}150 \infty \\
0 \% \\
0 \\
0\end{array}$ & $\begin{array}{l}\varrho=8= \\
000 \\
00\end{array}$ & 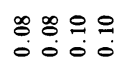 & 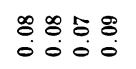 & 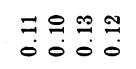 & 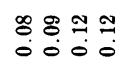 & $\begin{array}{l}\hat{0}: \\
\dot{0}:=1 \\
0: 0\end{array}$ \\
\hline 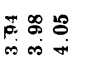 & 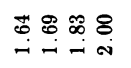 & 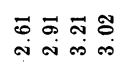 & 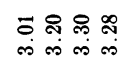 & 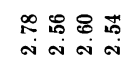 & 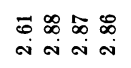 & 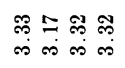 \\
\hline 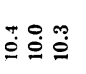 & 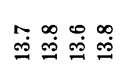 & 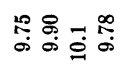 & 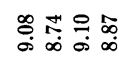 & 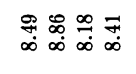 & 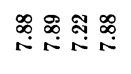 & 䨱 \\
\hline 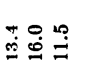 & 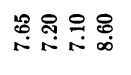 & 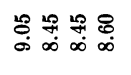 & 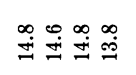 & 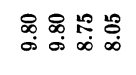 & 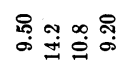 & 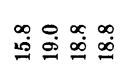 \\
\hline 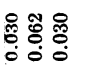 & 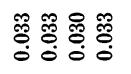 & 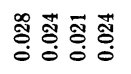 & 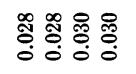 & 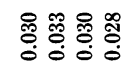 & 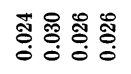 & 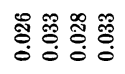 \\
\hline 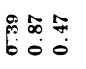 & 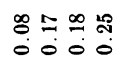 & 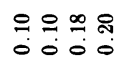 & 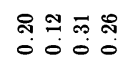 & 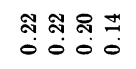 & 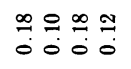 & 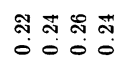 \\
\hline 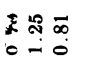 & 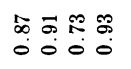 & 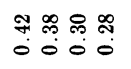 & 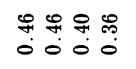 & 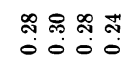 & 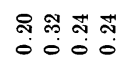 & 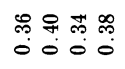 \\
\hline $\begin{array}{l}888 \\
100\end{array}$ & $\begin{array}{l}8=8 \\
0.00 \\
000\end{array}$ & $\begin{array}{l}8888 \\
0000 \\
000\end{array}$ & 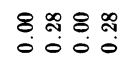 & $\begin{array}{l}8888 \\
000 \\
00\end{array}$ & $\begin{array}{l}888.8 \\
000 \\
000\end{array}$ & 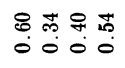 \\
\hline 总电禺 & 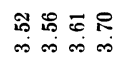 & 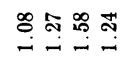 & 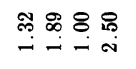 & 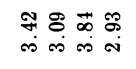 & 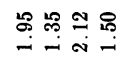 & 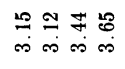 \\
\hline$\stackrel{0}{\dot{0}} \overrightarrow{\dot{0}}$ & 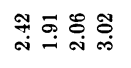 & 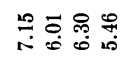 & 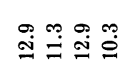 & 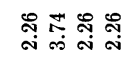 & 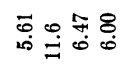 & 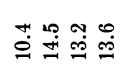 \\
\hline 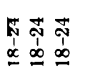 & I0 1000 & $\overbrace{b}^{\infty} \stackrel{\infty}{b} \frac{\infty}{b} \frac{\infty}{b} \frac{\infty}{b}$ & 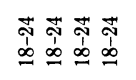 & 01000 & $\frac{\infty}{b} \frac{\infty}{b} \frac{\infty}{b} \frac{\infty}{b} \frac{\infty}{b}$ & 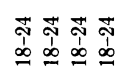 \\
\hline $\begin{array}{cc}\vdots & \vdots \\
\vdots & \vdots \\
x & 0\end{array}$ & \begin{tabular}{ccc}
$\vdots$ & $\vdots$ \\
$\vdots$ & $\vdots$ \\
\hdashline & $\vdots$ & $\vdots$ \\
0
\end{tabular} & $\begin{array}{ccc}\vdots & \vdots & \vdots \\
\vdots & \vdots & \vdots \\
0\end{array}$ & $\begin{array}{cc}\vdots & \vdots \\
\vdots & \vdots \\
0 & \vdots \\
0\end{array}$ & $\begin{array}{ccc}\vdots & \vdots & \vdots \\
\vdots & \vdots & \vdots \\
\vdots & 0 & \end{array}$ & $\begin{array}{c}\vdots \\
\vdots \\
\vdots\end{array}$ & 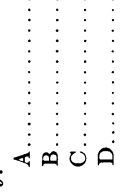 \\
\hline
\end{tabular}




\section{LITERATURE CITED}

Bower, C. A., and E. Truog

1940. Base exchange capacity determination as influenced by the nature of cation employed and formation of basic exchange salts. Soil Sci. Soc. Amer. Proc. 5:86-89.

Eaton, F. M.

1950. Significance of earbonates in irrigation waters. Soil Sci. 69:123-33.

Harding, R. B., P. F. PratT, and W. W. Jones

1958. Changes in salinity, nitrogen, and soil reaction in a differentially fertilized irrigated soil. Soil Sci. $85: 177-84$.

HARNED, H. S., and B. B. OWEN

1950. The physical chemistry of electrolytic solutions. New York: Reinhold Pub. Corp. (2d ed.) $645 \mathrm{pp}$.

Hutchinson, H. B., and K. MacLennan

1914. The determination of soil carbonates. Jour. Agr. Sci. $6: 323-27$.

RICHARDS, L. A. (editor)

1954. Diagnosis and improvement of saline and alkali soils. U.S. Dept. Agr. Handbook No. 60. Govt. Print. Off., Washington, D.C.

Reitemeier, R. F.

1946. Effect of moisture content on dissolved and exchangeable ions of soils of arid regions. Soil Sci. 61:195-214. 
The journal Hilgardia is published at irregular intervals, in volumes of about 600 pages. The number of issues per volume varies.

Subscriptions are not sold. The periodical is sent as published only to libraries, or to institutions in foreign countries having publications to offer in exchange.

You may obtain a single copy of any issue free, as long as the supply lasts; please request by volume and issue number from:

Agricultural Publications

207 University Hall

University of California

Berkeley 4, California

The limit to nonresidents of California is 10 separate issues on a single order. A list of the issues still available will be sent on request. 